\title{
現住建物・宅地における 除染事業に関する報告
}

\author{
松岡 数憲 1 \\ 1正会員＼cjkstart株式会社フジタ＼cjkstart東北支店（†980-0803 宮城県仙台市青葉区国分町2-14-18） \\ E-mail:matsuoka@fujita.co.jp
}

福島第一原発事故により大量の放射性物質が放出され、福島県を中心に放射性物質による污染が広がっ た。放射線被ばく線量低減のため、国直轄または市町村発注により除染事業が行われている。本報告では、 福島県川俣町において平成24年度から実施されている除染事業の建設会社の担当者として、除染事業の実 績や課題を報告する。まず放射線強さの分布は、宅地や建物の部位により線量に大きな差異があり、これ は部材・材質による線量の違い、雨樋下など局所的に線量の高い場所があること等を例に説明する。続い て線量低減のために、様々な除染手段に取り組んだので、その結果を述べる。さらに山林除染は面積が広 大にもかかわらず、充分な除染が難しい理由を指摘する。最後に除染効果の評価を述べ、除染事業を管理 寸る上での問題点・課題について述べる。

Key Words : Nuclear plant accident, Radioactive Contamination, Decontamination operations

\section{1. はじめに}

福島第一原発事故により放出された放射性物質による 被ばく線量を低減させるため、除染事業が実施されてい る。本報告文の対象としている福島県川俣町福沢地区は、 事故を起こした福島第一原発から北西 $47 \mathrm{Km}$ 、阿武隈高 地北部の丘陵地帯に位置する。町の中心部に接したとこ ろに一部平野がある他は、南側に向けて扇状に標高 200mから400mの丘陵地帯が広がる。起伏に富んだ丘陵 地帯は、山林が面積のほとんどを占め、狭い谷間の土地 に田畑が広がり、民家が斜面に点在する。民家の敷地は $1,000 \mathrm{~m}^{2}$ を超える世帯が多く、母屋の他に倉庫や土蔵が 建ち、民家の裏に勾配が急な山林を背負っている世帯が 多い。平成24年度から実施した現住建物・宅地約400軒 の除染事業について、放射能強さの分布や除染の方法や 効果、課題を報告する。

\section{2. 放射性物質による污染の分布}

福島第一原発事故を原因として、原発周辺から北西方 向、阿武隈高地の市町村を中心に、放射性物質が蓄積さ れた。放射能污染の高い地区では、住民は避難生活を続 けている。川俣町は福島第一原発から北西に概小 $35 \mathrm{~km}$ から $50 \mathrm{~km}$ の距離に位置し（図一1）、線量が比較的高

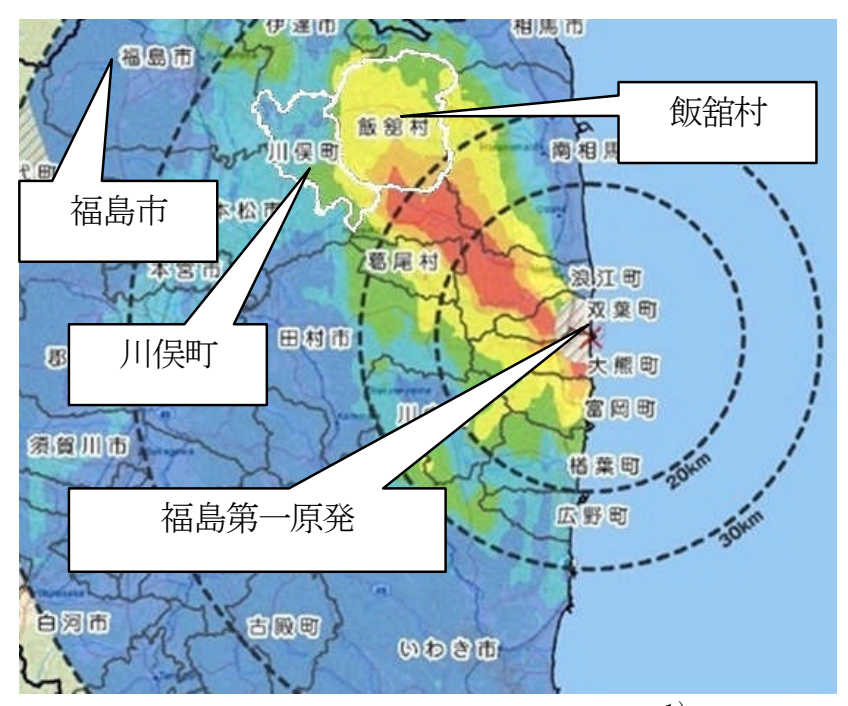

図-1 川俣町と福島第一原発の位置関係 ${ }^{1)}$

く、避難生活を余儀なくされている山木屋地区を含んで いる。

川俣町福沢地区では事故後、概ね高さ $1 \mathrm{~m}$ の空間線量 $1.0 \mu \mathrm{Sv} / \mathrm{h}$ 程度であったのに対し、福沢地区から $14 \mathrm{~km}$ 離 れた飯舘村長泥地区は、事故直後 $19 \mu \mathrm{Sv} / \mathrm{h}$ を超えた。 (図一2) 長泥地区では、5 年以上居住が制限され、原則 立入禁止区域である帰還困難区域に指定されている。距 離が $14 \mathrm{~km}$ しか離れていないにもかかわらず、空間線量 が大きく異なるのは、標高差が $400 \mathrm{~m}$ 以上あることが要 因として考えられる。 


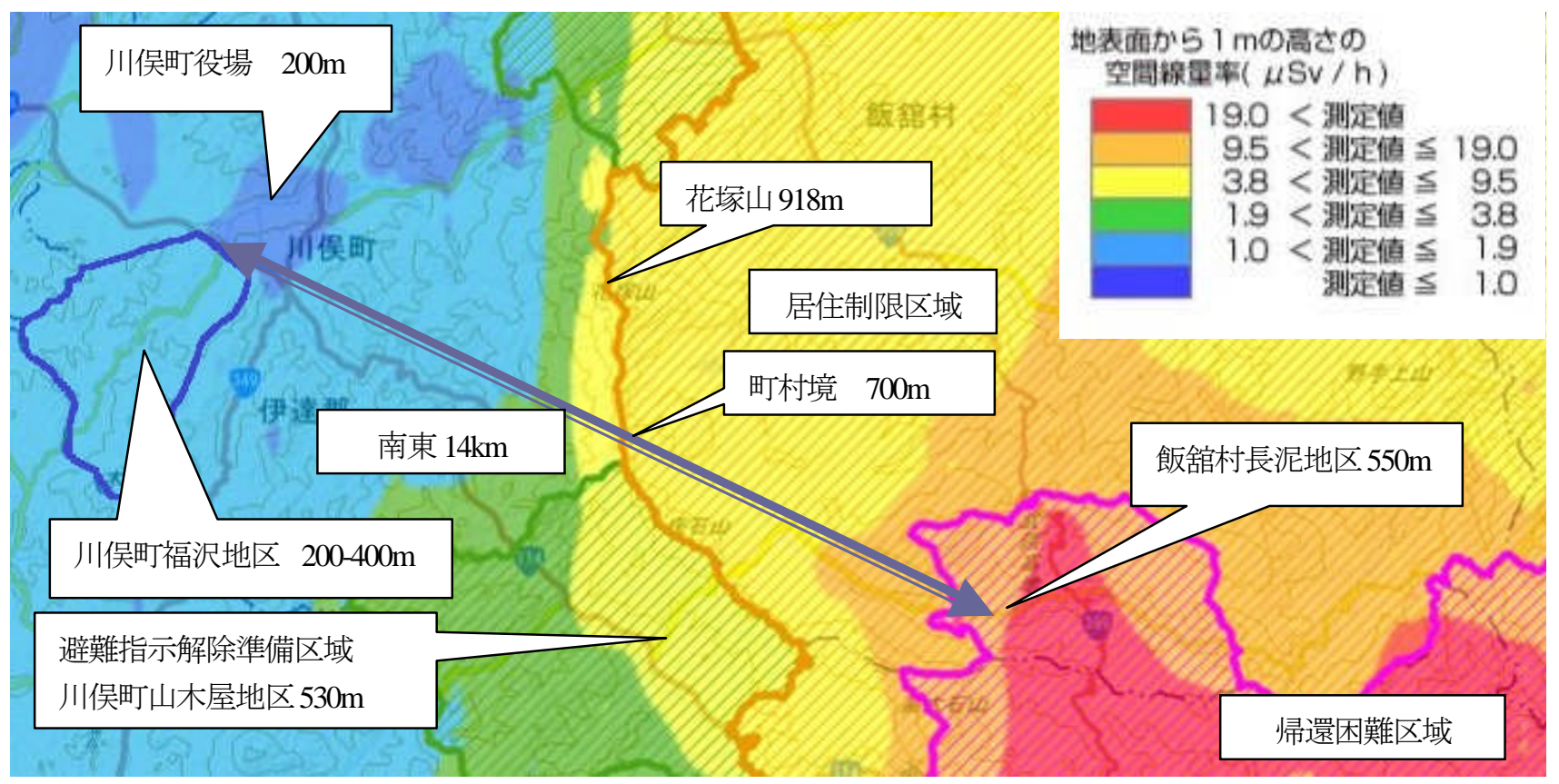

図-2 平成 23 年 4 月 29 日航空機によるモニタリング ${ }^{2)}$ 注） mは標高を示す

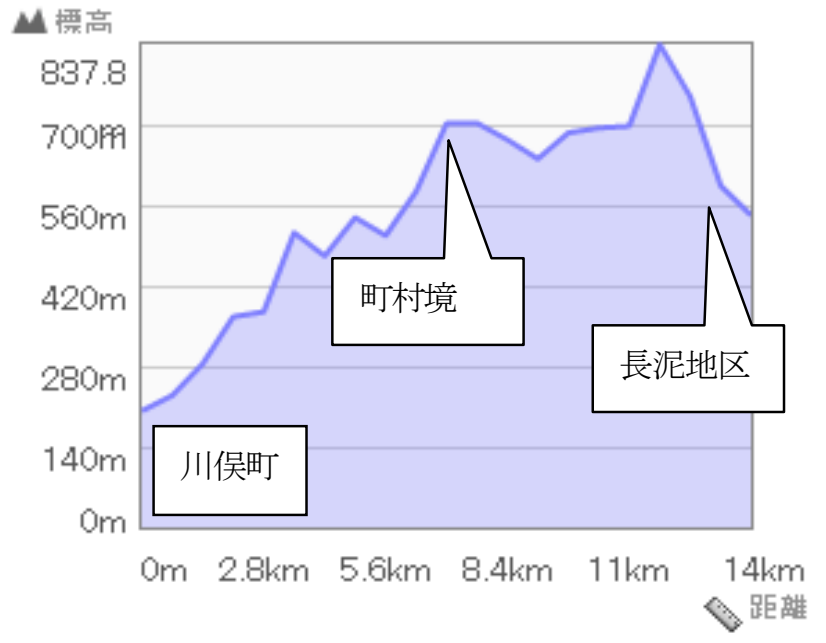

図-3 福沢地区から長泥地区までの標高 ${ }^{3)}$ (矢印の断面)

空間線量率の分布を示した(図一2)を見ると、川俣町 から南東方向へわずか $14 \mathrm{~km}$ の距離で、 $1.0 \mu \mathrm{Sv} / \mathrm{h}$ から $19.0 \mu \mathrm{Sv} / \mathrm{h}$ を超える值に線量があがっている。また同一 方向の標高断面を示した(図一3) を見ると、標高が 200mから 700m以上に上昇していることがわかる。標高 の高さと空間線量率の高さが比例していることが読み取 れる。

福島第一原発からの放射性物質の飛散は、飯舘村の標 高 $500 \mathrm{~m}$ から $900 \mathrm{~m}$ の山地で多く、川俣町の平野部では 少量にとどまり、標高差による差異が認められる。

\section{3. 除染作業とは}

\section{（1）国または市町村による除染事業}

福島第一原発の事故により放射性物質による環境污染 が生じたため、放射性物質污染対処特措法が施行され、 この法に基づき除染事業を進められることとなった。除 染寸る地域は、年間被ばく線量が $20 \mathrm{mSv}$ 以上もしくは福 島第一原発から半径 $20 \mathrm{~km}$ 圈内の地域は、国が主体とな り除染を実施し、20mSv 未満の地域は市町村が除染計画 を作成し実施する。今回の福沢地区の除染事業は、20m $\mathrm{Sv}$ 未満の地域であるため、川俣町が除染計画を作成し 発注した。

\section{(2) 除染の事前作業}

除染を実施するにあたり、各世帯を訪問し、屋根・雨 樋・壁といった建物、さらに庭・側溝・雨水枡といった 敷地や隣接森林等の放射線量を測定し、事前モニタリン グデータとしてまとめた。測定データは、空間線量 $\mathrm{Sv}$ （シーベルト）と表面污染密度(cpm)の 2 つである。福 沢地区の除染着手前（平成 24 年 10 月）の空間線量は、 $1 \mathrm{~m}$ の高さで概ね $0.6 \mu \mathrm{Sv} / \mathrm{h}$ から $1.0 \mu \mathrm{Sv} / \mathrm{h}$ であった。な お除染目標は長期的に $0.23 \mu \mathrm{Sv} / \mathrm{h}$ （年間 1 ミリ Sv）とさ れている。

線量測定後、行政区ごとに町主催の住民説明会が開催 され、町役場担当者と JV 職員と共同で、各世帯個別に 事前モニタリングデータを示し、除染方法を説明した。 住民から除染に同意が得られた場合、除染作業を実施す ることとした。 


\section{(3) 除染作業の実施}

除染作業とは、降下し蓄積した放射性物質を当該箇所 から除去させることである。除染方法は、「除染関係ガ イドライン」環境省 ${ }^{4)}$ 、「除染業務に係る技術指針」 福島県 ${ }^{5}$ 等により、除染の手順やフローが工種ごとに定 められている。例えば表土の剥ぎ取りでは、線量測定、 土工、客土、敷均し・締固め、仮置場へ搬出といったフ ローが示されている。作業員に定められた手順を具体的 に説明し、除染にあたらせた。

民家での除染作業にあたっては、作業員 6 名程度の班 を編成して、通常の民家は 1 班、敷地面積の広い家では 2 班を投入し実施した。特に屋根の作業には危険が伴う ため、作業担当をあらかじめ決めて配置した。平均 4 日 程度で 1 軒の家は完了寸るが、敷地面積が広大な家、特 に隣接森林の面積が広いと 1 軒で 1 か月以上かかる場合 もあった。作業員には事前モニタリングの值を示し、高 い污染箇所を周知させ、特に重点的に除染作業にあたる 場所を明示した。また簡易線量計を持たせて、除染箇所 の効果の確認を随時行った。

除染完了後、放射線量を事後モニタリングとして測定 し、除染前のデータと併せ、書面にまとめて、除染効果 を住民に周知した。

\section{(4) 仮置き場の確保}

除染で生じた污染物は、可燃物・不燃物に分けて袋詰 め（大型土のう）にして、地区の仮置き場に移動させた。 仮置き場に集積させた大型土のうは将来的に町外設置の 中間貯蔵施設に搬出する計画である。中間貯蔵施設とは、 除染土壌など（大型土のう）を最終処分までの間、安全 に集中的に貯蔵する施設であり、双葉町及び大熊町が候 補地となっているが、除染実施時に両町の地元同意が得 られていなかった。川俣町の仮置き場から中間貯蔵施設 への搬出時期が不透明な状況にあるので、発注者である 川俣町は、仮置き場の確保について、住民同意を得るこ とに多大な労力を要した。

\section{（5）作業員の被ばく管理}

厚生労働省では、除染作業員の被ばくの低減対策と して、「東日本大震災により生じた放射性物質により污 染された土壌等を除染するための業務等に係る電離放射 線障害防止規則」（除染電離則）を施行した。当除染現 場においても、除染電離則にもとづき、除染作業員の被 ばく線量管理等の措置をとった。

\section{4 建物・宅地内の放射線強さ}

\section{(1) 放射線の強さの分布}

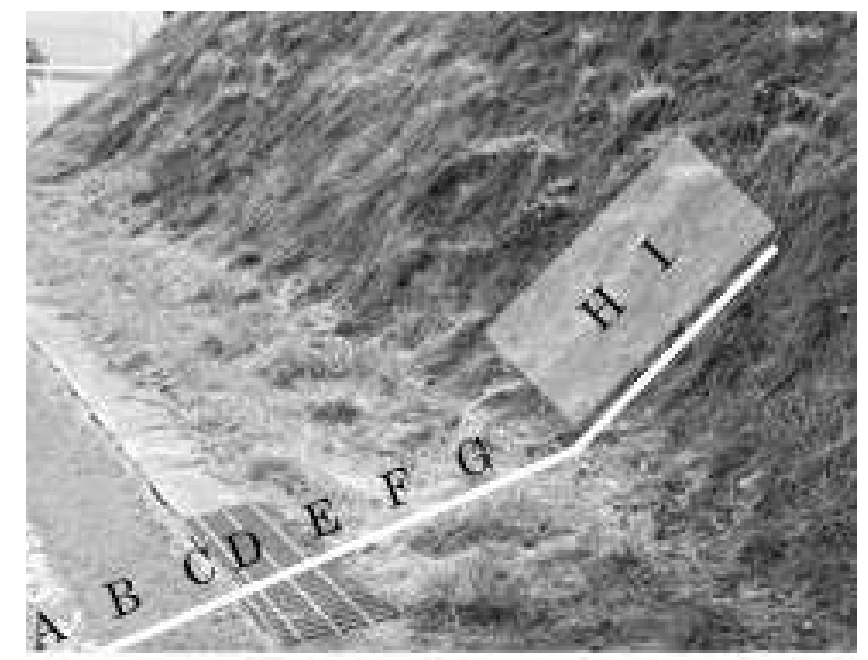

図-4＼cjkstart法面から道路において線量測定

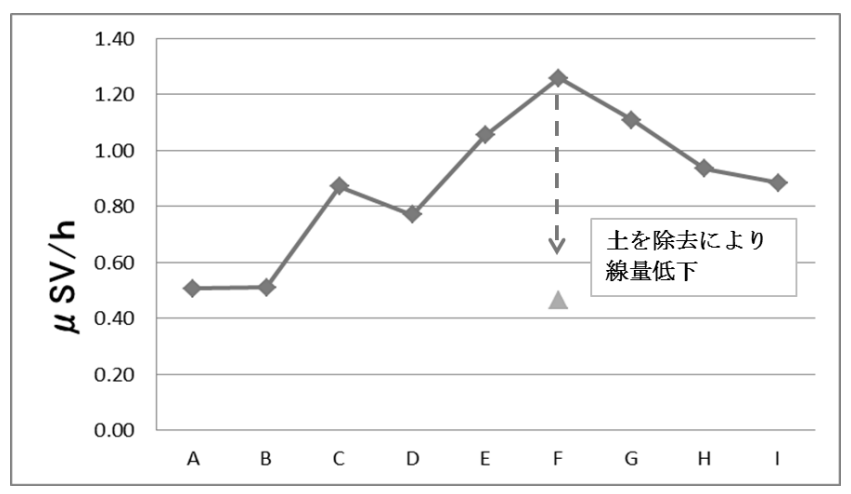

図-5＼cjkstart図-4の各点で空間線量測定した結果

福島第一原発の事故により拡散した放射性物質は、主 に降雨により地表に落下した。雨水に含まれた放射性物 質は、雨水の集まるところで濃縮され、その部分では線 量が高いとされる。除染にあたっては、事前に線量測定 したのち、小区画に除染試験を行い、低減効果を確認し たのち、例えば除草までか表土剥ぎ取りまでかを決定す る。 ${ }^{5}$ 以下、小区画での試験の例を示すこととする。 道路の法面・路肩・側溝上・舗装部でNaIシンチレー ションサーベイメータを用いて放射線量を測定した例を 示す。除染対象の表面污染の程度を測定するため、測定 点 $1 \mathrm{~cm}$ において、空間線量を計測した。データは、各 点ごと $50 \mathrm{~cm}$ の間隔をおいて3測線について測定し、3点 の平均を求めた。また除草を行った後、表土を除去した 後、各段階での放射線量の変化を測定した。

\section{a) 道路から法面を線量測定}

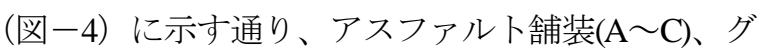
レーチング上 $(\mathrm{D}) 、$ 路肩 $(\mathrm{E} \sim \mathrm{G})$ 、法面 $(\mathrm{H} ・ \mathrm{I})$ において、 各々高さ1 $\mathrm{cm}$ での空間線量を測定した。AからI点それぞ れ3点の平均の結果は、(図一5) のとおりである。雨水 が溜まりやすい路肩上 (F) が最も高く、アスファルト上 (A, B)が低いことがわかる。 


\section{b) 路肩・法面の除草実施}

路肩・法面上では、洋芝が生え、比較的根が深く伸び

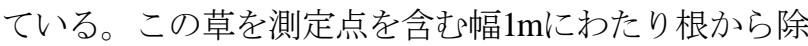
草し、露出した土の上で線量を再度測定した。結果は、 F点で $1.26 \mu \mathrm{Sv} / \mathrm{h}$ から $1.23 \mu \mathrm{Sv} / \mathrm{h}, \mathrm{I}$ 点で $0.88 \mu \mathrm{Sv} / \mathrm{h}$ から $0.82 \mu$ $\mathrm{Sv} / \mathrm{h} （ 50 \mathrm{~cm}$ ごと3点測定し平均值）と、除草では充分な 線量低下は確認できなかった。

原発事故後 2 年経過しており、その間に除草を何度か 行っていたので、すでに草にはほとんぞ放射能物質は付 着していないと考えられる。この場所においては、根も 含めた除草だけでは、除染に結びつかないと判断できる。

\section{c) 路肩の土を除去}

除草後、F点を含む路肩上の土を $30 \mathrm{~cm}$ 四方、深さ $10 \mathrm{~cm}$ 除 去した。F点で空間線量を測定すると、0.46 $\mu \mathrm{Sv} / \mathrm{h}$ と值 は半分以下となっていた。(図一-5)放射性物質を含ん だ土壌の多くは除去されたといえ、除染効果が確認で きる。除染はこの土壤を除去することが目標となる。 除染作業は事前に線量を測定し、試験的に剥ぎ取り深度 と低減率を確認しながら、剥ぎ取り厚さを決定する。4

放射線の強さ分布は、同一宅地の中でも場所により差 異があるので、除染にあたっては事前の測定と、適宜効 果を確認することが重要である。

今回測定データ $0.46 \mu \mathrm{Sv} / \mathrm{h}$ は高さ $1 \mathrm{~cm}$ のポイントで あり、除染後のウェザリング効果等によりさらなる低減 が期待できるので、最終的な除染目標である高さ $1 \mathrm{~m}$ に おける $0.23 \mu \mathrm{Sv} / \mathrm{h}$ は可能な值と考えることができる。

\section{5. 部位別 除染方法について}

\section{（1）屋根の材質による差異}

屋根に付着した放射性物質は、室内の放射線線量に 影響するので、線量が高い場合は極力落とす必要がある。 屋根に付着している苔、泥は高い污染源となっているこ とが多いが、堆積物除去・ブラッシング・拭き取りによ り除去すると、ほとんどの場合線量は大きく低減する。 問題は表面の污れを除去しても、線量が落ちない場合で ある。

屋根材は大きく分けて、粘土系（瓦）・セメント系 （瓦）・スレート系・金属系に分かれる。除染前屋根の 表面污染度 (屋根上 $1 \mathrm{~cm}$ )を測定し、素材別に平均したグ ラフを、（図一6）に示す。測定件数は、粘度系 45 件、 セメント系 3 件、スレート瓦 8 件、金属系 27 件である。 セメント系（瓦）・スレート瓦は、表面污染度が高いこ とがわかる。粘土系は粘土を使った焼き物の屋根材で、 主なものは粘土瓦である。粘土系や金属系は除染前から 污染度が低く、表面の污れを拭き取るとほとんどの場合、 線量は基準值内まで低減する。一方セメント系・スレー
卜系屋根は、元々放射線量が高いばかりか、拭き取り等 によっても線量が充分に落ちない場合が多い。これはセ メント系・スレート系屋根は、多孔質であるため、放射 性物質が内部に入り込みやすく、かつ除去しにくいのが 原因として考えられる。

\section{(2) スレート瓦の除染}

福沢多目的集会場の屋根はスレート瓦となっており、 表面污染密度が 2,000cpm から 3,000cpm を超えていた。通 常の除染方法ではほとんど值が低減することがなかった。 そこで除染方法として、「スチーム洗浄」と剥離剤と湿 布等を組み合わせた方法を川俣町に提案し、「平成 24 年度川俣町実証的除染事業」5) とし実施した。

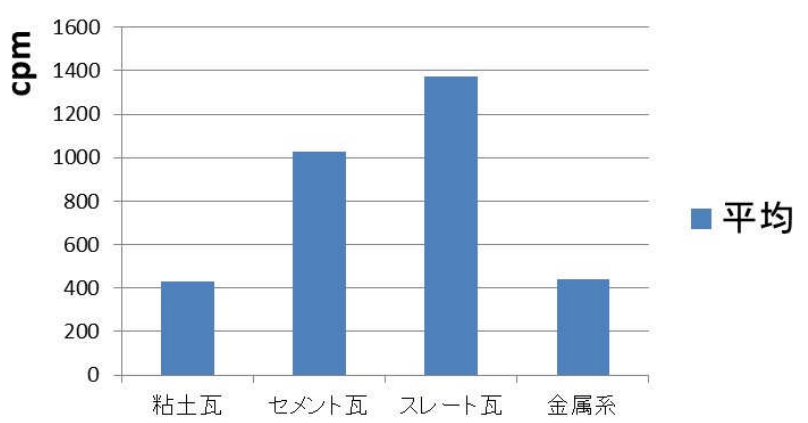

図-6＼cjkstart屋根材質による表面污染 (cpm) の違い

スチーム洗浄とは、水を気体の状態（水蒸気）にし、 污染面に噴射して污れを基材面から遊離させて洗浄する 工法である。屋根上での高圧洗浄は屋内への水漏れの卜 ラブルが続き、使用を控えていたが、スチーム洗浄は、 水漏れ可能性が少ない、スレート瓦を破損寸る恐れが少 ない、污染水の発生量・飛散防止が抑制されるという利 点を持つ。除染手順の概要は、(1)洗剤を塗布、湿布を 60 分もしくは 120 分敷き、洗剤が蒸発せずに屋根内部 に染み込むのを待つ、(2)蒸気（スチーム）洗浄を実施す る。(1)と（2)を繰り返した。その結果、表面污染密度 (cpm)は、60 分、120 分の箇所でそれぞれ 2, 260 cpm から 1,960cpm、2,460cpm から 2060cpm に、13\%から 16\%の低減 効果が確認された。屋根上での高圧洗浄は、水漏れの恐 れから実際は困難であるが、「スチーム洗浄」による除 染には一定の効果が期待できる。

\section{（3）雨樋下の除染 ホットスポットの存在}

雨水が集中的に集まる所では、ホットスポットと呼 ばれるように限られた範囲で極端に高い線量を示寸場所 がある。特に建物の雨樋下は線量が高い。今回の除染対 象のうち、栗和田地区 23 軒 44 点の雨樋下の表面污染密 度を測定したところ、除染前で平均 2,593 cpm という高い 值を示した。栗和田地区全体の測定点 784 点平均 $693 \mathrm{cpm}$ と比較して高く、除染目標 $1,000 \mathrm{cpm}$ に比較してもかなり 
高い值である。除染直後に線量低下しても、数日後再び 上昇することが多々あり、手直しをするケースが続いた。 原因としては、屋根をブラッシングで洗浄した後、拭き 取りしきれなかった放射性物質が、降雨の際に雨樋下に 集まったと推測できる。作業員には、雨樋下は線量が高 く、除染後再度上昇する場合があることを周知させ、日 時を変えて複数回除染するよう作業を指示した。最終的 には雨樋下除染後の平均は 448cpm まで低下した。

雨樋の下がひびの入ったアスファルト等の場合、内 部に放射能物質が入り込んでいると考えられ、高圧洗浄 を繰り返しても線量低下は困難である。アスファルト表 面を削る、もしくは表面にオーバーレイするといった措 置を検討したが、発注者の除染項目に含まれないので実 施することはできなかった。

また雨樋下に排水溝が埋められている場合、その地 中内部の線量が影響すると考えられる。地中の排水溝は 高圧洗浄を使っても、内部まで除染が十分にできないの で、線量低下が得られない場合が多い。

ただ雨樋下は高い線量を示すことが多いが、それは 高さ $10 \mathrm{~cm}$ 、範囲 $50 \mathrm{~cm}$ 四方に満たない局所的な場合がほ とんどである。雨樋下の周辺の測定点が、特に線量が高 く再除染が問題となることはなかったので、生活する住 民への影響を過剰に心配する必要はないと考えられる。

なお、発注者川俣町から環境省に集水枡（雨樋下） の局所的に高い線量への対処方法を問い合わせたところ、 以下回答が得られた。「除染の効果は、個別対象の表面 污染密度や局所的な空間線量率で判断するのではなく、 人が比較的多くの時間を過ごすことが想定される場所の 空間線量率で判断することとしています。集水枡につい ても、再度除染してもその効果は限定的となると考えら れることから、周辺の除染の効果とあわせ総合的に判断 いただくように御願いいたします。」としている。

\section{6. 宅地隣接森林の除染について}

\section{(1) 宅地隣接森林除染の問題点}

福沢地区は山林部分が面積の大半を占めるが、山林 の大部分は急傾斜地であり、重機が入らず、人力中心に なることから除染は元々困難である。また今回の除染は 生活圈を対象とするものであり、山林除染は宅地に隣接 する 20 メートル範囲に線引きされている。平成 24 年度 川俣町の除染においては、20メートル範囲においても、 傾斜地では土の剥ぎ取りは土砂の流出を引き起こす危険 があるので、民家の屋根高さに相当する斜面までに除染 範囲が限定された。住民からは、山林の除染が不十分で あるから、周辺山林から宅地に放射性物質が流れ込み， 再び宅地の放射線量が上がるという不安感が指摘されて
いる。

\section{(2) 隣接森林土袞の剝ぎ取り試験}

隣接森林の土壌表面から、土の剥ぎ取り深さを変え て、それぞれ表面污染密度を測定した。

\section{a) 測定手順}

周辺山林において、比較的平坦な場所を 1 箇所選定 し、約 $1 \mathrm{~m}^{2}$ の範囲で落葉及び腐植土の剥ぎ取りを行った。

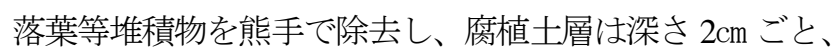
計 $6 \mathrm{~cm}$ までスコップを用いて剥ぎ取りを行い、各層につ き中央で 1 点、表面污染密度を測定した(各層とも測定 は1回)。

\section{b) 表面污染密度の測定結果}

表面污染密度の測定結果を表一 1 に示す。剥ぎ取り前 の状態で表面污染密度は620cpmであったが、落葉除去後 $780 \mathrm{cpm}$ 、腐植土 $2 \mathrm{~cm}$ 剥ぎ取り後 $700 \mathrm{cpm}$ と剥ぎ取り前より高 い值を示した。腐植土 $4 \mathrm{~cm}$ 剥ぎ取り後では $310 \mathrm{cpm} 、 6 \mathrm{~cm}$ は270cpmと剥ぎ取り前に比べて減少した。

表-1＼cjkstart森林土壌剥ぎ取りによる表面污染密度

\begin{tabular}{|l|r|}
\hline & 表面污染度 \\
\hline cpm \\
\hline 剥ぎ取り前 & 620 \\
\hline 落葉除去後 & 780 \\
\hline 2 c m剥ぎ取り後 & 700 \\
\hline 4 c m剥ぎ取り後 & 310 \\
\hline 6 c m剥ぎ取り後 & 270 \\
\hline
\end{tabular}

\section{c) 考察}

表面污染密度の測定データを見ると、落葉のある表面 から腐植土深さ $2 \mathrm{~cm}$ 剥ぎ取りまでは、剥ぎ取り前よりも 逆に高い值を示す。これは、(1)腐植土深さ2cmまでは、 2011年秋、2012年秋の落葉が積み重なっており、放射性 物質の污染が少ない。(2)原発事故直後に落葉に付着した 放射性物質は、雨水により腐食土層に内部 $2 \mathrm{~cm}$ より深い 層に浸透している。(3)落葉表面から深さ $2 \mathrm{~cm}$ までの間の 層は放射線を遮へいする役割を果たしている。と考えら れる。よって線量を半減させるためには、 $4 \mathrm{~cm}$ 以上土壌 を除去する必要があることがわかる。

\section{（3）隣接森林除染の範囲拡大}

実際の周辺山林の除染では、急勾配の法面では崩落 の危険性から、腐植土 $2 \mathrm{~cm}$ 程度の除去にとどまること が多かった。その結果、除染後の線量測定で除染前より も高く出るポイントが散見された。前述の試験で示され たとおりである。なお平成 25 年度隣接地区での除染工 事では、隣接森林範囲について、屋根の高さまでという 制限がなくなり、原則 20 メートル範囲とされた。それ とともに急斜面の除染においては、崩落防止のために 
「植生シート」敷設などの項目が追加となった。

\section{(4) 隣接森林からの放射性物質流出}

福沢地区の全体面積は $8.5 \mathrm{~km}^{2}$ であり、今回除染した 宅地・道路・宅地周辺山林の面積を合計すると $0.8 \mathrm{~km}^{2}$ となり、全体の $9.3 \%$ に過ぎない。広大な面積を占める 山林の多くは除染対象外である。山林の放射性物質が流 れ宅地の線量が再び上がるという恐れは、当然のこと住 民から指摘されている。

環境省は、森林内に溜まった放射性物質が、生活範 囲に流出寸る量はかなり小さいと考えられるとしている。 例えば川俣町山木屋地区では、スギ若齢林に設置した試 験斜面枠 $\left(110 \mathrm{~m}^{2}\right)$ から流出した放射性物質を調查した ところ、流出率 $0.2 \%$ という結果を示している ${ }^{6)}$ 。森林 からの放射性物質の流出は、微量であるという研究結果 である。

除染を行っていない森林部では、現在も比較的線量が 高く、福沢地区では $1 \mathrm{~cm}$ で $1 \mu \mathrm{Sv} / \mathrm{h}$ を超えるところが多 い(平成 27 年 5 月の值)。一方、福沢地区の小川で 3 箇所水質検査を実施したところ、放射性物質は測定下限 以下であった。（平成 27 年 5 月の值）森林から流水、 小川を通じての放射性物質の流出は、あったとしても極 めて少量であると考えられる。

\section{7. 除染の効果・持続性について}

\section{（1）除染の効果について}

国の機関である原子力災害対策本部は除染目標につい て、放射性物質の物理的減衰及び風雨などの自然要因に よる減衰（ウェザリング効果）によって、推定年間被ば く線量が約40\%減少するとしており、さらに除染によっ て線量の低下を迅速化させるとしている。（図一7)

除染による線量低下目標は、少なくとも約10\%（子ど もの生活空間は約20\%）低減させるとされ、ウェザリン グ効果等と併せて、計50\%（子どもの生活空間は60\%） 線量低下を実現させるとしている9”。

今回の除染では空間線量率 $(\mu \mathrm{Sv} / \mathrm{h})$ では西福沢地区 $32.4 \%$ 東福沢地区 $39.5 \%$ (図一 は西福沢地区 $56.9 \%$ 、東福沢地区60.7\%（図一9)の低減率 が得られた。（測定ポイントの除染前後の平均を比較） また環境省は2012年3月～2013年10月に、国直轄及び市 町村で実施された除染事業のデータをまとめ低減率を算 出している ${ }^{10)}$ 。除染前 $1 \mu \mathrm{Sv} / \mathrm{h}$ 未満の地域では、「国直 轄事業十市町村事業 全地域」では平均的な低減率は $32.3 \%$ でる。除染前に測定点の半数が $0.48 \mu \mathrm{Sv} / \mathrm{h}$ 以下で あったが、除染後は半数が $0.32 \mu \mathrm{Sv} / \mathrm{h}$ 以下に低減した。 「市町村事業 住宅地」では21.4\%の低減率となってい

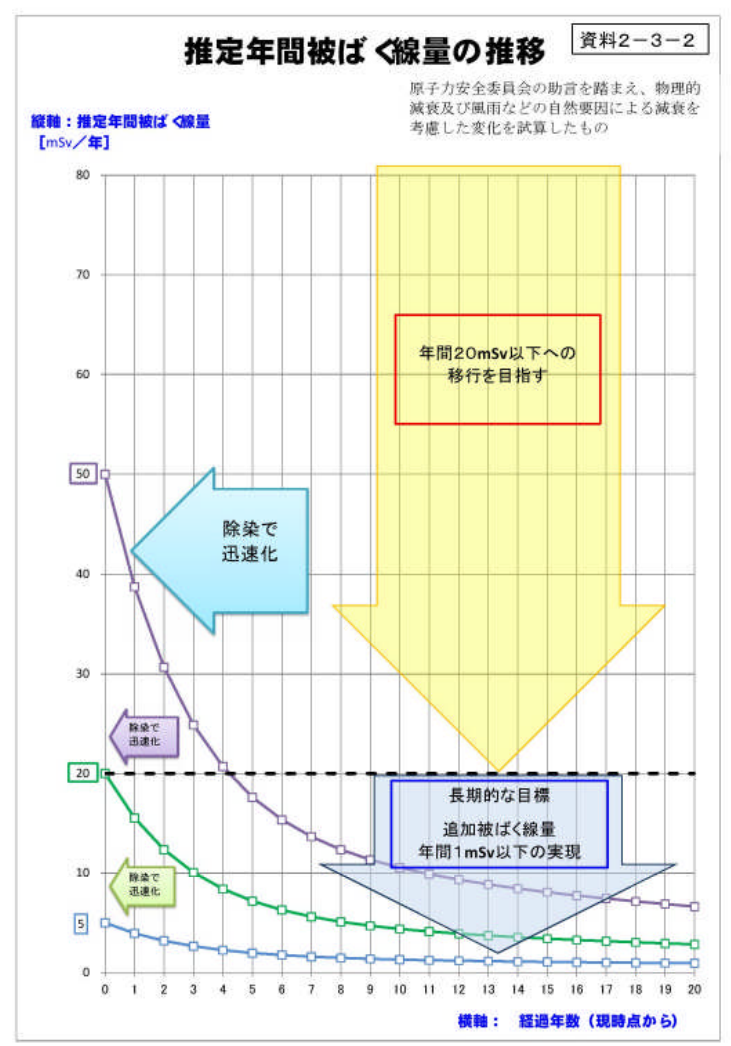

図-7 推定年間被ばく線量の推移 ${ }^{8)}$

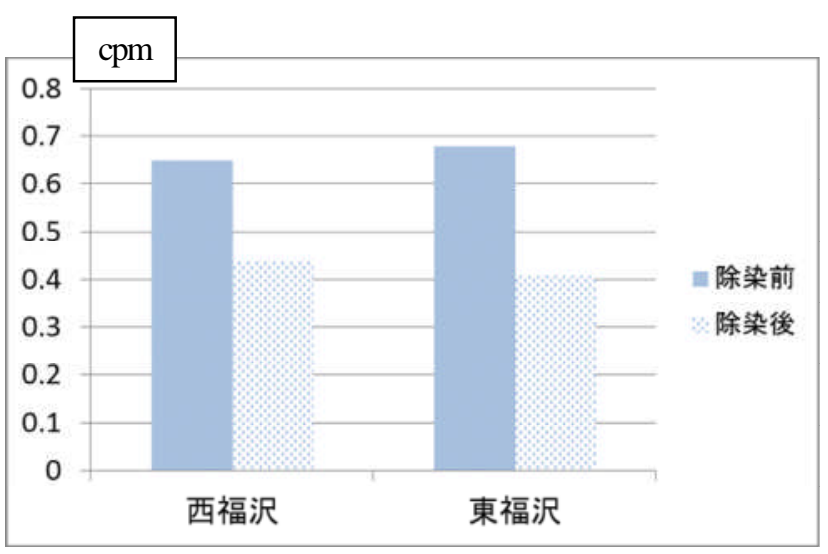

図-8 除染前後 空間線量 $(\mu \mathrm{Sv} / \mathrm{h})$ 比較

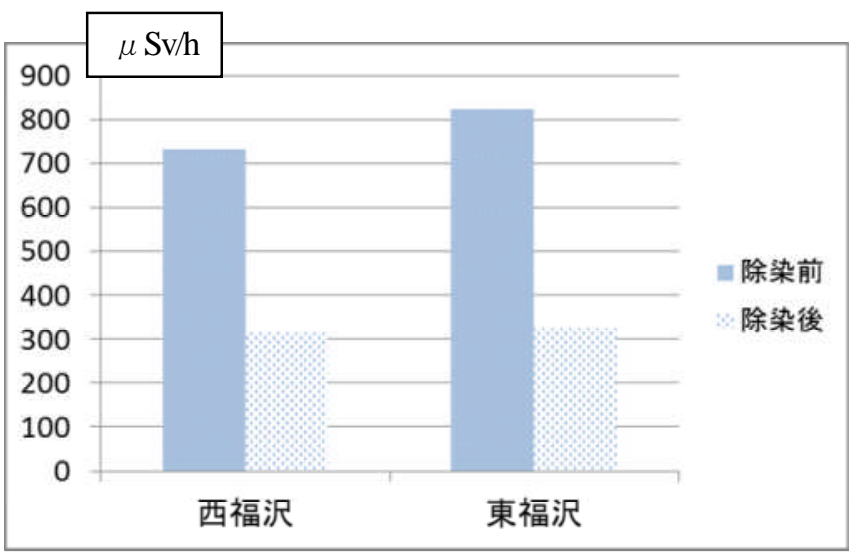

図-9 除染前後 表面污染 $(\mathrm{cpm})$ 比較 
る。除染事業は、国の当初の目標を上回った低減率を実 現している。

\section{（2）除染効果の持続性について}

除染により放射線量を低下した住宅地が、周辺山林の 影響を受けて再び線量を上昇させることはないだろうか。 それを判断するには、継続的なデータ観測が必要である。 今回除染した施設のうち、福沢公民館（生涯学習セン夕 一) に、モニタリングポストが設置され、除染前の2012 年8月から現在まで空間線量データが継続的に収集され、 原子力規制委員会のホームページにデータが開示されて いる ${ }^{11)}$ 。その内、2012年8月から2014年4月までの空間線 量の值をグラフ化したもの（図一10）に示す。ちなみに この施設は「福沢地区」除染範囲のほぼ中央、標高約 250メートルの窪地に位置する。

除染を実施したのは2012年10月下旬から11月下旬であ るが、その間線量は $0.8 \mu \mathrm{Sv} / \mathrm{h} か ら 0.4 \mu \mathrm{Sv} / \mathrm{h}$ に急激に下が っていることがわかる。2013年2月、2014年2月に一時的 に線量低下が見られるが、これは積雪の影響である。

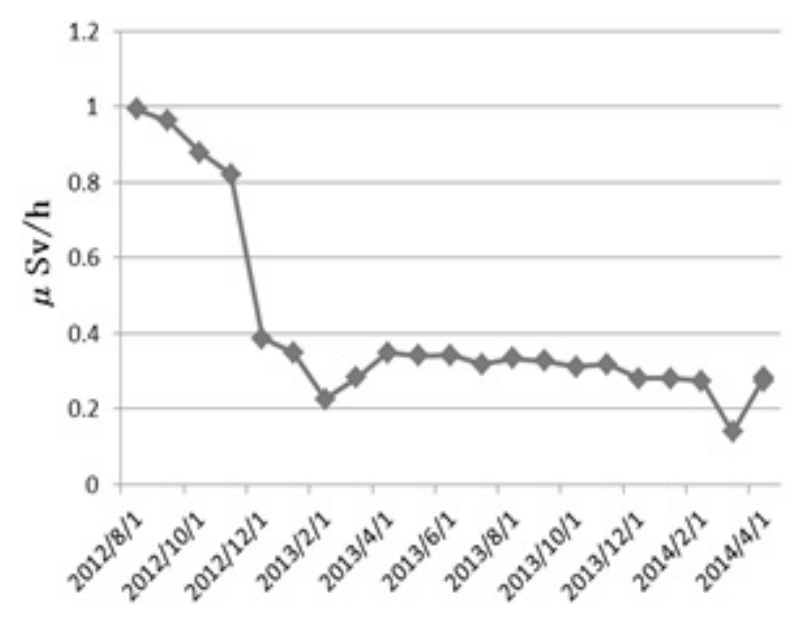

図-10 除染前後 空間線量推移（福沢公民館） 11 )

2014年4月まで空間線量は僅かずつではあるが低下傾 向を見せており、この低下傾向が反転する兆しは現れて いない。2015年5月現在も $0.3 \mu \mathrm{Sv} / \mathrm{h}$ を切る值を示してお り、除染の効果は持続している。他の福沢地区のモニタ リングポストも同様の傾向を示している。

\section{8. 除染実施にあたっての問題点}

\section{（1）住民対応について}

今回の原発事故の放射能污染は、住民にとっては被害 者であり、除染を要求することは当然のことである。震 災後 1 年以上たってようやく除染が始まったこともあり、 住民の不満は大きかった。住宅の除染にあたっては、家
屋が老朽化していたため屋根上の作業の影響で雨漏りが 生じた、庭木を誤って切ってしまった、庭の球根が土と 共に除去されてしまったといった多様なトラブルが生じ、 対応に苦労した。数軒ではあるが、庭の除染では専門の 庭師を希望する世帯もあったが、福島県の除染指針にな いケースなので、発注者を含めた協議に時間を要した場 合もあった。なお、公共施設の除染では、コンクリート の表面がはがれ、鉄筋が露出しているところがあり、補 修を提案したが、除染の目的外支出となるとのことで、 実施されなかったことを参考のため述べる。

\section{(2) 作業員の確保}

除染事業では、建物の除染以外に、仮置き場の造成、 大型土のう運搬等にも作業員を必要とする。福島県内各 地で除染事業が進められている中で、作業員の確保は大 きな課題となり、作業員の技量の差や定着率の悪さに悩 まされた。

\section{(3) 事務管理の効率化}

今回での仕事では、除染対象となる住民との対応、多 数の作業員管理が大きな課題であった。また放射線量測 定データや除染対象数量算定に関する資料作成の多さも、 相当な負荷となった。除染事業の進捗とともに、提出寸 る書類は増加傾向にあるので、事務効率化を進めていく 必要がある。

\section{9. 今後の課題}

今回の報告では、放射性物質による污染の強さは、同 じ宅地内においても場所や部位により差が大きいことを 示し、森林除染の課題を示した。また除染の効果や持続 性を示した。除染事業の最終的な目標は、被ばく線量が 低減されて、住民が安心して生活できる環境を取り戻す ことである。低線量被ばくの身体一の影響は、専門家の 間でも意見が分かれる。今回の除染事業は、「低い線量 での除染作業は寸る必要がない」という批判と、「除染 してもすぐ線量があがり、効果ない」という批判もある。 とはいえ、除染による線量低下は、データから明らかで あるので、住民の安心に寄与していることは間違いない。 なお平成26年事業として、福沢地区の山林部分の対象 を拡大して、除染事業が実施されている。

除染の課題としては、(1)住民の安心のため除染効果の 継続的モニタリングを行うこと、(2)効率的かつ効果的な 除染手法の開発、(3)仮置場に置かれた大型土のう搬出 （大型土のう耐用保証 5 年）があげられる。福島第一原 発事故に被災した福島復興のため、除染への取組みが今 後とも幅広く求められている。 
謝辞 : 本報告文の執筆にあたり、発注者である福島県川 俣町、フジタ安齋土木共同企業体、協力会社をはじめ多 くの皆様のご協力に厚く御礼申し上げます。

\section{参考文献}

1)原子力規制委員会 : 放射線モニタリング情報ホーム ページ: 平成 23 年 4 月 航空機モニタリングによる 空間線量率 $(\mu \mathrm{Sv} / \mathrm{h}) 、 \mathrm{http}: / /$ radioactivity.nsr.go.jp/ja

2)放射線量等分布マップ拡大サイトホームページ： http://ramap.jaea.go.jp/map/

3) YAHOO!ホームページ地図 : http://map.yahoo.co.jp/

4) 環境省: 除染関係ガイドライン 第 2 版: 平成 25 年 5 月

5) 福島県：除染業務に係る技術指針 第 2 版、平成 26 年 2 月 28 日

6) フジタ・安齋土木共同企業体 : 平成 24 年度川俣町実
証的除染事業実施結果、2013

7) 環境省：家のそばの森はどうやって除染するの 〜 森林除染について〜,平成 26 年 1 月

8) 原子力災害対策本部：配布資料 推定年間被ばく線 量の推移、平成 23 年 8 月 26 日

9) 原子力災害対策本部：除染に関する緊急実施基本方 針、平成 23 年 8 月 26 日

10）環境省除染チーム：国及び地方自治体が実施した除 染事業における除染の効果（空間線量率）について、 環境回復検討会（第 10 回）資料、平成 25 年 12 月 26 日

11）原子力規制委員会 : 放射線モニタリング情報ホーム ページ：全国及び福島県の空間線量測定結果、 http://radioactivity.nsr.go.jp/map/ja/

\section{Reduction of the radioactive contamination in the house with the The Fukushima Daiichi nuclear power plant accident}

\section{Kazunori MATSUOKA}

A large amount of radioactive substances is released by the Fukushima Daiichi nuclear power plant accident, it has spread radioactive contamination around the Fukushima Prefecture. Because of reduction of the radioactive contamination, decontamination project is being carried out by the country under the direct control or municipal order. In this report, as the person in charge of the decontamination operations, which has been implemented from the 2012 fiscal year in the Fukushima Prefecture, Kawamata Town, reports the achievements and challenges of the decontamination operations. First distribution of radiation strength is made higher in the place where gather the rain water even in the same land, also dose difference of by material, explaining that there is a high place locally dose rain trough. Subsequently, reports various decontamination means and describe the result. Furthermore forest area despite the vast, point out the reason why sufficient decontamination is difficult. Last-mentioned evaluation of decontamination effects, I describe problems and challenges in managing the decontamination operations. 